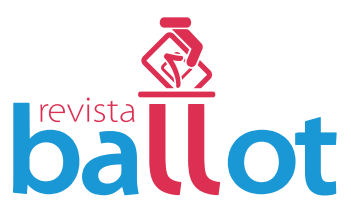

\title{
Anticorruption in Brazil: How Brazilian Companies Should Deal with Requirements of the FCPA and of the Brazilian Anticorruption Act
}

\author{
Alberto Monteiro (Columbia Law School, Estados Unidos) \\ aam2242@columbia.edu. \\ 116th Street and Broadway \\ New York, NY 10027
}




\title{
Resumo
}

O enforcement anticorrupção vem crescendo de forma vigorosa em várias partes do mundo recentemente. Essa tendência envolve a investigação de casos não apenas dentro das fronteiras de certo país, mas também esquemas internacionais. Talvez o primeiro país a enfrentar a corrupção internacional, os Estados Unidos aprovaram o Foreign Corrupt Practices Act em 1977. No Brasil, o governo aprovou a Lei Anticorrupção em agosto de 2013 com o objetivo principal de responsabilizar pessoas jurídicas por atos de corrupção. $\mathrm{O}$ objetivo do presente artigo é analisar a interação de ambas as leis, avaliar onde elas convergem ou divergem, e tentar estabelecer o que empresas sujeitasàs duas leis precisam fazer para cumprir ambas.

Palavras-chave: Compliance, FCPA, Anticurrupção, Corrupção.

\begin{abstract}
The anticorruption enforcement has been increasing vigorously in various parts of the world in recent years. This trend has involved prosecution of cases occurred not only within the borders of a given country, but also foreign and cross border schemes. Perhaps the first country to engage in the enforcement against international corruption, the United States passed the Foreign Corrupt Practices Act in 1977. In Brazil, the government passed the Anticorruption Act in August 2013 with the main goal of putting legal entities on the hook for acts of corruption. The aim of this paper is to analyze the interaction of both statutes, evaluate where they converge or diverge, and try to establish what companies that are subject to the two statutes need to do to be in compliance with both.
\end{abstract}

Keywords: Compliance, FCPA, Anticorruption, Corruption. 


\section{Introduction}

The anticorruption enforcement has been increasing vigorously in various parts of the world in recent years. This trend has involved prosecution of cases occurred not only within the borders of a given country, but also foreign and cross border schemes.

According to a report issued by the Organization for Economic Co-operation and Development ("OECD") 1 in 2014, international efforts to challenge bribery have increased noticeably since the implementation of the Convention on Combating Bribery of Foreign Public Officials in International Business Transactions ("OECD Anti-Bribery Convention") in 1997. The OECD's report analyzed more than 400 cases in 41 countries and highlighted the efforts with insights into how, where and to whom bribes are being paid and how such crimes are being sanctioned ${ }^{2}$.

Perhaps the first country to engage in the enforcement against international corruption, the United States passed the Foreign Corrupt Practices Act ("FCPA") in $1977^{3}$ for the purpose of making it unlawful for certain classes of persons and entities to make payments to foreign government officials to assist in obtaining or retaining business ${ }^{4}$. Although many believe today that the US Government passed the FCPA to become the anticorruption inspector of the world, the real aim at the time was to stop the practice of various US corporations regarding bribery of foreign officials and to restore public confidence in the integrity of the American business system ${ }^{5}$.

The anti-bribery provisions of the FCPA apply to all US persons, certain foreign issuers of securities and, after amendments passed in 1998, also to foreign firms and persons who cause, directly or through agents, an act in furtherance of such a corrupt payment to take place within the territory of the United States ${ }^{6}$.

Brazil is frequently ranked in corruption indexes prepared by international and non-governmental organizations as a country with high levels of corruption. The organization Transparency International released data regarding the levels of corruption perception in the public sector around the world in 2012 (2012 Global Perception Index $)^{7}$. Brazil received 43 points, occupying the $69^{\text {th }}$ position in a ranking going from 1 (best position) to 176 (worst

1. OCED (2014), OECD Foreign Bribery Report: An Analysis of the Crime of Bribery of Foreign Public Official, OECD Publishing. Available at http://www.keepeek.com/Digital-Asset-Management/oecd/governance/ oecd-foreign-bribery-report_9789264226616-en\#page1.

2. New OECD Report Provides Insight into Foreign Bribery, We Comply (Dec 9, 2014), available at http:// www.wecomply.com/blog/post/2462052-New-OECD-Report-Provides-Insight-into-Foreign-Bribery

3. 15 U.S.C. $\$ \$ 78 d d-1$.

4. Foreign Corrupt Practices Act - an overview, DOJ, available at http://www.justice.gov/criminal/fraud/fcpa/.

5. In the in the mid-1970s, several U.S. companies admitted making payments to foreign government officials and politicians, and political parties. One major example was the Lockheed bribery scandals, in which officials of aerospace company Lockheed paid foreign officials to favor their company's products. Another was the Bananagate scandal in which Chiquita Brands had bribed the President of Honduras to lower taxes.

6. Foreign Corrupt Practices Act - an overview, DOJ, available at http://www.justice.gov/criminal/fraud/fcpa/.

7. Corruption Perception Index 2012, Transparency International, available at thttps://www.transparency.org/ cpi2012/results. 
position). According to the publication, any score less than 50 (the case of Brazil) represents a serious indication of corruption. Although Brazil signed the OECD Anti-Bribery Convention, the enforcement of the Convention is considered "little" in Brazil by the report "Exporting Corruption? Country Enforcement Of The OECD Anti-Bribery Convention Progress Report 2012"8 produced by Transparency International.

There are various types of conduct associated with "corruption" and these are covered in different statutes under Brazilian law. Although the crimes of active and passive corruption - narrowly defined - and other related conducts are defined under the Brazilian Criminal Code, provisions contained in other statutes refer to conducts which could be classified as "corruption" under a broader definition?.

Despite these laws, until very recently there was a feeling in Brazil that acts of corruption were not properly investigated and punished in the country, leaving a sense of impunity. One can notice, however, a change in the recent years where the authorities have been showing a concern with the prosecution and adequate punishment of acts of corruption, greatly as a result of public pressure coming from the streets. A big example was the so-called Mensalão Scandal ${ }^{10}$. The case involved a vote-buying scheme that almost brought down the government of Luiz Inácio Lula da Silva in 2005. The scandal broke on June 6, 2005 when Brazilian Congressional Deputy Roberto Jefferson told the Brazilian newspaper Folha de São Paulo that the Partido dos Trabalhadores (Workers Party - PT) had paid a number of Congressional deputies thousands of reais every month in order to vote for legislation favored by PT. The funds were said to originate from state-owned companies advertising budgets. ${ }^{11}$ In this case, many politicians were indicted and sent to jail in the context of the Criminal Lawsuit No. 470 for the crime of passive corruption.

Another display of public dissatisfaction with corruption in Brazil was the demonstrations of June 2013, where millions of Brazilians went to the streets at the same time in different states of the country to protest against the conditions of public transportation, education, health and against corruption more generally ${ }^{12}$. As a result of the protests, the Government passed the Law No. 12.846 in August 2013 ("Brazilian Anticorruption Act") ${ }^{13}$. The main goal of the new law was to also put legal entities on the hook for acts of corruption, since the Brazilian Criminal Code is applicable only to individuals and the burden of proof is high in such cases.

\section{EXPORTING CORRUPTION? COUNTRY ENFORCEMENT OF THE OECD ANTI-BRIBERY CONVENTION, PROGRESS REPORT 2012, Transparency International, available at http://www. transparency.org/whatwedo/publication/exporting_corruption_country_enforcement_of_the_oecd_anti_ bribery_conventio. \\ 9. Among other statutes in Brazil that cover conducts associated with corruption, one can mention Admin- istrative Misconduct Act (Law No. 8.429/92) and the Public Bidding Law (Lei n. ${ }^{\circ}$ 8.666/1993).}

10. Lula's scandal-hit ally impeached, BBC News (Dec 1st, 2005), available at http://news.bbc.co.uk/2/hi/ americas/4487266.stm.

11. Mensalão scandal, Wikipedia, available at http://en.wikipedia.org/wiki/Mensalão_scandal

12. Protests in Brazil: the streets erupt, The Economist (Jun 18, 2013), available at http://www.economist. $\mathrm{com} /$ blogs/americasview $/ 2013 / 06 /$ protests-brazil?spc $=$ scode\&spv $=x m \&$ ah $=9 \mathrm{~d} 7 \mathrm{f} 7 \mathrm{ab} 945510 \mathrm{a} 56 \mathrm{fa} 6 \mathrm{~d} 37 \mathrm{c}$ $30 \mathrm{~b} 6 \mathrm{f} 1709$

13. Law No.12.846, of August 1st, 2013, available at http://www.planalto.gov.br/ccivil_03/_ato20112014/2013/lei/l12846.htm 
The Act is based on the FCPA and on the UK Bribery Act and provides for civil and administrative liability of legal entities, including private and governmental companies, for acts of corruption of Brazilian companies against national or foreign public administrations. Foreign companies with activities in Brazil can also be punished for corruption acts carried out in the Brazilian territory. The Act provides for the strict corporate liability and the subsidiary liability of the legal entities that belong to the same economic group. It also provides for fines of up to $20 \%$ of company gross revenues, in addition to the prohibition of contracting with the Public Administration and participating in public bids for a period of 5 years, among other provisions.

Considering the above, after the enactment of the Brazilian Anticorruption Act, it is clear that there are Brazilian companies (or foreign companies with activities in Brazil) subject to both the FCPA and the Brazilian Anticorruption Act. The aim of this paper is precisely to analyze the interaction of both statutes, evaluate where they converge or diverge, and try to establish what companies that are subject to the two statutes need to do to be in compliance with both.

The first conclusion that I outline here is that there is no direct contradiction between the FCPA and the Brazilian Anticorruption Act; in other words, none of the two statutes mandates companies to do something that represents a violation of the other law. This is good news for the companies subject to both. However, there are still some inconsistencies between both that are worth noting and to which companies should be attentive to avoid liability. In the case of such discrepancies, companies should, of course, do what the stricter of the two laws mandates, even if this represents being over conservative in light of the other law. I analyze below the main potential inconsistencies between the FCPA and the Brazilian Anticorruption Act.

\section{Comparative analysis of the FCPA and the Brazilian Anticorruption Act}

\section{1 . What is a public official?}

Under the FCPA, it is unlawful to bribe officials of foreign governments or of any "instrumentality" thereof. What entities are included as instrumentalities of a foreign government is not defined in the FCPA and there has been intense divergence over the scope of the term. However, since most of the FCPA cases end up in settlements, this term is rarely litigated.

On May 16, 2014, in United States v. Esquenazi ${ }^{14}$, the Eleventh Circuit affirmed a broad definition of "instrumentality" of a foreign government to define who qualifies as a "foreign official" under the FCPA. The court provided a two-part definition of "instrumentality" as (i) "an entity controlled by the government of a foreign country" that (ii) "performs a function the controlling government treats as its own." The court also laid out a non-exhaustive list of factors to consider in applying each part of the test ${ }^{15}$.

14. United States v. Esquenazi, No. 11-15331, 2014 U.S. App. LEXIS 9096 (2d Cir. May 16, 2014), available at http://www.ca11.uscourts.gov/opinions/ops/201115331.pdf.

15. Eleventh Circuit Adopts Broad Definition of Government "Instrumentality” Under FCPA, Wilmer Hale (May 22, 2014), available at https://www.wilmerhale.com/pages/publicationsandnewsdetail. aspx?NewsPubId $=17179872427$ 
The Article 5 of the Brazilian Anticorruption Act considers it an illegal act to offer an undue advantage to a public official or third person related thereto. However the law brings no definition of "national public official", leaving the concept open in a way that one needs to find a definition for the term in other laws. In that regard, the Decree-Law 200 of $1967^{16}$ establishes that the Federal Public Administration corresponds to (i) the Direct Administration; and (ii) Indirect Administration.

According to this law, the Direct Administration consists of integrated services in the administrative structure of the Presidency and Ministries. On its turn, the Indirect Administration includes an exhaustive list of categories of entities with legal personality: (i) Autarquias (public bodies with separated legal personality), (ii) public companies (companies owned by the Government), (iii) Sociedades de Economia Mista (companies where the majority of the voting shares belong to the Government), and (iv) Public Foundations. The members of the Direct and of the Indirect Administrations seem to represent what the Brazilian Anticorruption Act considers to be national public officials.

On the other hand, the Brazilian Anticorruption Act brings a definition of what constitutes foreign public official. According to Article 5 of the law, foreign public officials include those who, even if temporarily or without remuneration, hold position, employment or public function in bodies, state agencies or diplomatic representations of foreign countries, as well as in legal entities controlled directly or indirectly by the government of a foreign country. Still according to the same provision, international public organizations are treated as foreign governments for purposes of the law.

It is my understanding that all the entities that are considered public officials for purposes of the Brazilian Anticorruption Act (either national or foreign officials) are encompassed by the FCPA definition of officials of foreign governments or instrumentalities thereof. In view of this, although companies should be mindful to the Brazilian definition of public officials when designing their anticorruption policies and practices, I understand that the guidance provided by the FCPA is still the best thermometer for purposes of concept of public officials.

\section{$2+2$. What is an improper payment?}

In broad terms, the FCPA forbids the payment of anything of value to foreign officials with the purpose of retaining business. However, the statute or regulations related thereto bring no clear definition of what "anything of value" means.

The DOJ and the SEC have traditionally advocated an open definition for the expression "anything of value" and it appears to remain their policy moving forward. As stated by the SEC in a recent conference regarding FCPA enforcement, the US Government will "continue to pursue a broad interpretation of the FCPA that precludes bribery in all forms," including "cash, gifts, travel, entertainment or employment of the family and friends of foreign officials." ${ }^{17}$

16. Decree-Law 200, of February 15, 1967, available at http://www.planalto.gov.br/ccivil_03/decreto-lei/ del0200.htm.

17. Compliance Programs, Self-Reporting Important in Today's FCPA Enforcement Environment, Officials Say, Sandler, Travis \& Rosenberg Trade Report (Dec 4, 2014), available at http://www.strtrade.com/newspublications-FCPA-SEC-DOJ-enforcement-compliance-120414.html. 
The FCPA Resource Guide published by the DOJ and the Securities Exchange Commission ("SEC") in 2012 goes in the same direction and state that "[a]n improper benefit can take many forms. While cases often involve payments of cash (sometimes in the guise of 'consulting fees' or 'commissions' given through intermediaries), others have involved travel expenses and expensive gifts. Like the domestic bribery statute, the FCPA does not contain a minimum threshold amount for corrupt gifts or payments. Indeed, what might be considered a modest payment in the United States could be a larger and much more significant amount in a foreign country. Regardless of size, for a gift or other payment to violate the statute, the payor must have corrupt intent-that is, the intent to improperly influence the government official. The corrupt intent requirement protects companies that engage in the ordinary and legitimate promotion of their businesses while targeting conduct that seeks to improperly induce officials into misusing their positions. ${ }^{18}$ In that sense, anything of value can mean, cash, gifts, travel, entertainment, charitable donations, among other things.

The Brazilian Anticorruption Act considers a violation to promise, offer or give, directly or indirectly, "undue advantage" to a public official or third party related thereto. Similarly to the FCPA, the law gives no definition for "undue advantage", but there is no case law or public statements or policies by the Brazilian authorities providing guidance on the matter, which represents a problem.

It is worth noting that the traditional crimes of active and passive corruption established by the Brazilian Criminal Code (applicable only to individuals) also use the language of undue advantage and the criminal case law could be useful for interpreting the Brazilian Anticorruption Act.

Under the Brazilian Criminal Code, the crimes of "passive corruption" involve a situation where (i) a public official receives some kind of "undue advantage" (e.g. for delaying or failing to perform an act he/she should perform or by practicing acts in violation to his/her duties); and the crime of "active corruption" involves a situation where (ii) a private party offers a public offical an "undue advantage" (e.g. gifts, payments or privileges) so that the public servant will practice or fail to practice a certain act.

Under the tradition case law, the crime of active corruption only occurs if the agent acts with the willful intention (dolo) of offering or promising an undue advantage to the public official, aiming at convincing the public official to perform, refrain from performing, or delay the performance of a certain act. There is no determination of a specific value that constitutes the crime of active corruption, being certain that any offer or promise of an undue advantage to a public official to influence him to practice a certain official act can be deemed as a crime, regardless of the amount.

If the Brazilian authorities decide to apply in cases involving the Brazilian Anticorruption Act a standard similar to the one used to interpret the Brazilian Criminal Code, it is possible to say that, in theory, the tests applicable in Brazil and in the US will be, at least in theory, relatively similar. Both focus on intent of the payor instead of determining a minimum threshold amount. However, the standard in Brazil still seems to be a little stricter than in the US, at least in principle. While the test in the US focus on context to determine the corrupt intent of the payor, the practice of the DOJ and the SEC seems to have established some areas that

18. A Resource Guide to the U.S. Foreign Corrupt Practices Act, SEC and DOJ (2012) pg. 14-15, available at http://www.sec.gov/spotlight/fcpa/fcpa-resource-guide.pdf. 
are almost safe harbors. As said in the FCPA Resource Guide, "it is difficult to envision any scenario in which the provision of cups of coffee, taxi fare, or company promotional items of nominal value would ever evidence corrupt intent, and neither DOJ nor SEC has ever pursued an investigation on the basis of such conduct. Moreover, as in all areas of federal law enforcement, DOJ and SEC exercise discretion in deciding which cases promote law enforcement priorities and justify investigation." ${ }^{19}$

Brazil, on the other hand, has not provided this guidance so far and one can find criminal cases of corruption where the payor was sentenced for the crime of active corruption even when paying a very small amount to a public official, but with a proof of the corrupt intent ${ }^{20}$.

In light of that, further guidance from the Brazilian authorities regarding the interpretation of "undue advantage" in the context of the Brazilian Anticorruption Act is clearly in need. Until then, the companies must be mindful to that and be conservative when designing their policies for dealing with public officials in Brazil.

\section{Facilitation payments and reasonable bona fide business expenditures}

The FCPA's only exception relates to "facilitating or expediting payment[s]" to foreign officials for the purpose of "expedit[in] or secur[ing] the performance of a routine governmental action." Courts have characterized facilitating payments as "essentially ministerial' actions that 'merely move a particular matter toward an eventual act or decision or which do not involve any discretionary action."'21

According to the FCPA Resource Guide ${ }^{22}$, the facilitation payments exception applies only when a payment is made to further "routine governmental action" that involves non-discretionary acts. Examples of "routine governmental action" include processing visas, providing police protection or mail service, and supplying utilities like phone service, power, and water ${ }^{23}$. Routine government action does not include a decision to award new business or to continue business with a particular party. Although the statute explicitly allows for facilitation payments, commentators point out that the DOJ and the SEC have construed the exception so narrowly that few are willing to rely on it. The DOJ's and the SEC's disapproval of facilitating payments encourages companies to prohibit or discourage facilitation payments ${ }^{24}$.

19. A Resource Guide to the U.S. Foreign Corrupt Practices Act, SEC and DOJ (2012) pg. 15, available at http://www.sec.gov/spotlight/fcpa/fcpa-resource-guide.pdf.

20. ACR 0034298-40.2010.8.19.0203 (Tribunal de Justiça do Rio de Janeiro - decided in 7/17/2013).

21. United States v. Kay, 359 F.3d 738, 761 (5th Cir 2004), citing H.R. Rep. No. 640, 95th Cong., 1st Sess. 8 (1977).

22. A Resource Guide to the U.S. Foreign Corrupt Practices Act, SEC and DOJ (2012) pg. 25, available at http://www.sec.gov/spotlight/fcpa/fcpa-resource-guide.pdf.

23. Section $30 \mathrm{~A}(\mathrm{f})(3)(\mathrm{B})$ of the Exchange Act, 15 U.S.C. $\$ 78 \mathrm{dd}-1(\mathrm{f})(3)(\mathrm{B}) ; 15$ U.S.C. $\$ \$ 78 \mathrm{dd}-2(\mathrm{~h})(4)$

$(B), 78 d d-3(f)(4)(B)$.

24. United States: The Disappearing Exception For Facilitating Payments: Agencies Take Narrow View Of This FCPA Defense, Mondaq (Fec 27, 2013), available at http://www.mondaq.com/unitedstates/x/224072/ White + Collar + Crime + Fraud/The + Disappearing + Exception + For + Facilitating + Payments + Agencies + T ake+Narrow+View+Of+This+FCPA+Defense 
The FCPA contains still two affirmative defenses: (1) lawful payment under the written laws of the foreign country (the "local law" defense), and (2) money spent as part of demonstrating a product or performing a contractual obligation (the "reasonable and bona fide business expenditure" defense). Because these are affirmative defenses, the defendant bears the burden of proving them.

According to the FCPA Guide, the FCPA allows companies to provide reasonable and bona fide travel and lodging expenses to a foreign official, and it is an affirmative defense where expenses are directly related to the promotion, demonstration, or explanation of a company's products or services, or are related to a company's execution or performance of a contract with a foreign government or agency ${ }^{25}$. Trips that are primarily for personal entertainment purposes, however, are not bona fide business expenses and may violate the FCPA's anti-bribery provisions ${ }^{26}$.

In sum, according to the DOJ and the SEC, these expenditures will not give rise to prosecution if they are (1) reasonable, (2) bona fide, and (3) directly related to (4) the promotion, demonstration, or explanation of products or services or the execution or performance of a contract ${ }^{27}$.

The Brazilian Anticorruption Act establishes no exemptions or affirmative defenses. So facilitation payments or reasonable business expenditures will be assessed under the general provision regarding the offer of "undue advantages" to public officials. This poses serious problems of transparency and predictability, since the Brazilian authorities have not yet provided further guidance on the matter, neither through regulations or public statements.

It is my understanding that facilitation payments will likely be considered a violation of the Brazilian Anticorruption Act, since the general test provided by the Brazilian criminal law for cases of active corruption involves the offer of any undue advantage to a public official to perform an official act, even if this act is already part of his routine action. In addition, as mentioned above, one can find criminal cases of corruption where the payor was sentenced for the crime of active corruption even when paying a very small amount to a public official.

In relation to the reasonable business expenditures, I believe that there would be stronger grounds to support that the act does not involve a violation of the Brazilian Anticorruption Act. Although further guidance from the Brazilian authorities on the matter is still needed, the test in the US seems to be a good standard for Brazil. It should not be a problem if the expenditure was (1) reasonable, (2) bona fide, and (3) directly related to (4) the promotion, demonstration, or explanation of products or services or the execution or performance of a contract. In any event, considering the lack of certainty, it is advisable that companies subject to both adopts conservative approaches regarding these business expenditures.

\footnotetext{
25. Section 30A(c)(2)(A), (B) of the Exchange Act, 15 U.S.C. $₫ 78 d d-1(c)$ (2); 15 U.S.C. $\$ \$ 78 d d-2(c)(2)$, $78 \mathrm{dd}-3(\mathrm{c})(2)$.

26. A Resource Guide to the U.S. Foreign Corrupt Practices Act, SEC and DOJ (2012) pg. 24, available at http://www.sec.gov/spotlight/fcpa/fcpa-resource-guide.pdf.

27. A Resource Guide to the U.S. Foreign Corrupt Practices Act, SEC and DOJ (2012) pg. 24, available at http://www.sec.gov/spotlight/fcpa/fcpa-resource-guide.pdf.
} 


\subsection{Cooperation and leniency}

According to the FCPA Resource Guide, "while the conduct underlying any FCPA investigation is obviously a fundamental and threshold consideration in deciding what, if any, action to take, both DOJ and SEC place a high premium on self-reporting, along with cooperation and remedial efforts, in determining the appropriate resolution of FCPA matters" ${ }^{\prime 28}$. The two main official documents governing the credit given to a company self-reporting a FCPA violation and cooperating with the authorities are the DOJ's Principles of Federal Prosecution of Business Organizations ("Principles of Federal Prosecution") and the United States Sentencing Guidelines (“USSG”).

The Principles of Federal Prosecution ${ }^{29}$ provide nine factors that a prosecutor should take into account when determining whether to bring charges, one of which is "the corporation's timely and voluntary disclosure of wrongdoing and its willingness to cooperate in the investigation of its agents." ${ }^{30}$ The Section "The Value of Cooperation" ${ }^{31}$ explains that, in determining the extent of the corporation's cooperation, the prosecutor "may consider, among other things, whether the corporation made a voluntary and timely disclosure, and the corporation's willingness to provide relevant information and evidence and identify relevant actors within and outside the corporation, including senior executives."

The other source of formal guidance regarding how self-reporting and cooperation are considered with respect to business organizations is the $\mathrm{USSG}^{32}$, which are advisory and not binding in nature after the Supreme Court decision in United States v. Booker ${ }^{33}$.

The USSG similarly take into account a defendant's cooperation and voluntary disclosure. Under $\$ 5 \mathrm{~K} 1.1$, a defendant's cooperation, if sufficiently substantial, may justify the government filing a motion for a reduced sentence. And under $\$ 5 \mathrm{~K} 2.16$, a defendant's voluntary disclosure of an offense prior to its discovery - if the offense was unlikely to have been discovered otherwise - may warrant a downward departure in certain circumstances ${ }^{34}$. Chapter 8 of the Sentencing Guidelines governs the sentencing of organizations. An organization's self-reporting, cooperation, and acceptance of responsibility may lead to fine reductions under $\S$ $8 \mathrm{C} 2.5(\mathrm{~g})$ by decreasing the culpability score $\mathrm{e}^{35}$.

Based on the above, it is possible to say that the level of credit for self-reporting and cooperation to be obtained by the defendants is left to the discretion of the SEC, the DOJ

28. A Resource Guide to the U.S. Foreign Corrupt Practices Act, SEC and DOJ (2012) pg. 54, available at http://www.sec.gov/spotlight/fcpa/fcpa-resource-guide.pdf.

29. USAM Chapter 9-28.000 et seq., available at http://www.justice.gov/usao/eousa/foia_reading_room/ usam/.

30. Id. Chapter 9-28.300: Factors to Be Considered, no. 4.

31. Id. Chapter 9-28.700.

32.2013 USSC Guidelines Manual is available at http://www.ussc.gov/guidelines-manual/2013-usscguidelines-manual.

33. United States v. Booker, 543 U.S. 220 (2005).

34. A Resource Guide to the U.S. Foreign Corrupt Practices Act, SEC and DOJ (2012) pg. 54, available at http://www.sec.gov/spotlight/fcpa/fcpa-resource-guide.pdf.

35. USSG $\oint 8 \mathrm{C} 2.5(\mathrm{f})(2)(2011)$

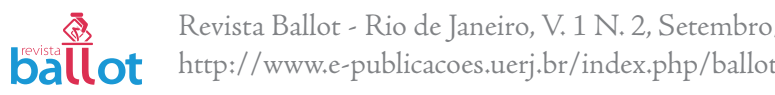


and courts when negotiating plea agreements and imposing fines, provided that the general guidance set by the documents referred to above is followed.

According to recent remarks by Assistant Attorney General Leslie Caldwell at New York University Law School's Program on Corporate Compliance and Enforcement on April 17 2015, Companies considering whether to seek cooperation credit must do more than simply conduct an internal investigation and report to the DOJ. To earn credit "we expect that company to conduct a thorough internal investigation and to turn over evidence of wrongdoing to our prosecutors in a timely and complete way. Perhaps more critically, we expect cooperating companies to identify culpable individuals-including senior executives if they were involved - and provide the facts about their wrongdoing." ${ }^{136}$

The Brazilian Anticorruption Act provides in its Article 16 that the authority can execute Leniency Agreements with the entities that practiced the illegal acts foreseen in the law, provided that 3 requirements are met: (i) the entity is the first to approach the authority to offer cooperation; (ii) the entity stops its involvement in the conduct; and (iii) the entity admits participation in the illegal act and cooperate fully with the investigations. The execution of the Leniency Agreement may reduce the fine imposed in an amount up to e 2/3 (two thirds) of the applicable fine.

As it is possible to note, self-reporting and cooperation involve somewhat different requirements and can trigger different results in both jurisdictions. The most import aspect is that, while an investigated party can approach the DOJ and SEC at any time to offer cooperation in exchange of some credit (being certain, of course, that timing and value of cooperation are key elements in the assessment of such credit), the Leniency Agreement in Brazil is available only to the first company that approaches the local authority to self-report and cooperate. It is not clear under the Brazilian Anticorruption Act whether a second-in or third-in approaching the authority will be able to negotiate a settlement and how much of credit for cooperation will be granted in such circumstances. There is no regulation or practice about the matter, which should be clarified by the authorities either by public statements or regulation. Until then, companies willing to cooperate both in Brazil and in the US should be mindful that so far the Leniency Agreement in Brazil is available only to the first-in.

\subsection{The value of an effective anticorruption compliance program}

In the US, an effective and well-structured anticorruption compliance program is valuable to detect, prevent and remediate violations within the company even before they occur or are discovered by the authorities. If the program fails, the wrongdoing takes place and authorities become aware of that (either through self-reporting or other sources), the effectiveness of the program is still of value, since it can help to determine which measure the DOJ or the SEC will take.

The DOJ and the SEC can consider the adequacy of the program when deciding whether or not to bring charges or resolve the issue through a deferred prosecution agreement ("DPA") or non-prosecution agreement ("NPA"). The influential SEC decision in the Seabo-

36. Internal Investigations and Cooperation Credit in FCPA Investigations, SEC Actions (Apr 17, 2015), available at http://www.secactions.com/internal-investigations-and-cooperation-credit-in-fcpa-investigations/. 
ard case ${ }^{37}$ mentions the existence of the effective compliance programs as one of the aspects to be considered when deciding to bring charges. Some of the nine factors of the DOJ's Principles of Federal Prosecution relate to the existence of structured compliance programs ${ }^{38}$. Finally, Section 8B2.1 of the USSG also takes into account the existence and strength of such programs as one of the factors that influence the amount of the potential fine.

According to the SEC and the DOJ, there are no formalistic requirements regarding such compliance programs. They employ a common-sense and pragmatic approach to evaluating compliance programs, making inquiries related to three basic questions:

+ Is the company's compliance program well designed?

+ Is it being applied in good faith?

+ Does it work? $?^{39}$

Under the FCPA Guide, the agencies cite 10 factors that represent hallmarks of an effective compliance program ${ }^{40}$. These factors are: (i) commitment from senior management and a clearly articulated policy against corruption; (ii) code of conduct and compliance policies and procedures; (iii) oversight, autonomy, and resources; (iv) risk assessment; (v) training and continuing advice; (vi) incentives and disciplinary measures; (vii) third party due diligence and payments; (viii) confidential reporting and internal investigations; (ix) continuous improvement: periodic testing and review; and $(\mathrm{x})$ mergers and acquisitions: pre-acquisition due diligence and post-acquisition integration.

The Brazilian Anticorruption Act mentions in its Article 7 that the existence of an effective compliance program is one of the factors that the authorities will take into account when determining the amount of the fine to be imposed. However, the statute provides no further guidance as to what is an effective compliance program.

On March 18, 2015, the Brazilian President signed a decree ${ }^{41}$ (the "Decree") that further regulates the Anticorruption Act and one of the aspects that deserved careful attention was precisely the requirements that a compliance program needs to meet to be considered effective. Article 42 of the Decree lists fourteen factors that need to be taken into consideration for that purpose, many of which resemble or basically repeat the factors that the DOJ and

37. Seaboard Report, note 298; U.S. Sec. and Exchange

Comm., Report of Investigation Pursuant to Section 21(a) of the Securities Exchange Act of 1934 and Commission Statement on the Relationship of Cooperation to Agency Enforcement Decisions, SEC Rel. No. 44969 (Oct. 23, 2001), available at http://www.sec.gov/litigation/investreport/34-44969.htm.

38. USAM $₫ 9-28.300$. When evaluating the pervasiveness of wrongdoing within the corporation, prosecutors are advised that while it may be appropriate to charge a corporation for minor misconduct where the wrongdoing was pervasive, "it may not be appropriate to impose liability upon a corporation, particularly one with a robust compliance program in place, under a strict respondeat superior theory for the single isolated act of a rogue employee." Id. \$ 9-28.500.A

39. A Resource Guide to the U.S. Foreign Corrupt Practices Act, SEC and DOJ (2012) pg. 56, available at http://www.sec.gov/spotlight/fcpa/fcpa-resource-guide.pdf.

40. A Resource Guide to the U.S. Foreign Corrupt Practices Act, SEC and DOJ (2012) pg. 57-62, available at http://www.sec.gov/spotlight/fcpa/fcpa-resource-guide.pdf.

41. Decree 8.420, of March 18, 2015, available at http://www.planalto.gov.br/ccivil_03/_Ato20152018/2015/Decreto/D8420.htm. 
the SEC consider relevant in the US, such as the commitment from senior management, continuous evaluation of risks, trainings, disciplinary measures, third party due diligence, pre-acquisition due diligence in mergers and acquisitions, among others.

Based on that, I understand that there is a significant overlap between the FCPA and Brazilian parameters for an effective compliance program. If the company has a program that is robust enough to meet the FCPA requirements, it will likely be in compliance with the Brazilian Anticorruption Act too. Of course, this fact does not excuse the companies from carrying out a detailed analysis of each factor mentioned in both laws, to make sure a complete observance of what they mandate. However, potential disparities between both laws do not appear to be a problem in this area.

\subsection{Books and records and internal controls provisions}

A final aspect that deserves a note relates to the accounting provisions that exist in the FCPA. The accounting provisions are generally designed to "strengthen the accuracy of the corporate books and records and the reliability of the audit process which constitute the foundations of our system of corporate disclosure."42

The accounting provisions consist of two primary components. First, under the "books and records" provision, companies must make and keep books, records, and accounts that, in reasonable detail, accurately and fairly reflect an issuer's transactions and dispositions of an issuer's assets. ${ }^{43}$ Second, under the "internal controls" provision, they must devise and maintain a system of internal accounting controls sufficient to assure management's control, authority, and responsibility over the firm's assets. ${ }^{44}$

The Brazilian Anticorruption Act does not contain books and records or internal controls provisions. Of course that there are other laws in the country that relate to accounting procedures and companies must be in compliance with them for reasons other than the Anticorruption Act. However, in that particular area, companies that are subject to both the Brazilian law and the FCPA must be aware that the FCPA imposes several requirements regarding accounting which do not exist in the Brazilian Anticorruption Act and which they must be in compliance with to avoid undesirable consequences.

\section{Conclusion}

The international enforcement of anticorruption laws has been a trend in recent years. This situation, fueled by the dissatisfaction of the Brazilian people with the levels of corruption in Brazil led the Government to pass the Brazilian Anticorruption Act, highly inspired by the FCPA.

After the comparative analysis of both laws carried out above, I close this paper with two brief final remarks.

\footnotetext{
42. S. Rep. No. 95-114, at 7.

43. Section 13(b)(2)(A) of the Exchange Act, 15 U.S.C. $\$ 78 \mathrm{~m}(\mathrm{~b})(2)(\mathrm{A})$.

44. Section 13(b)(2)(B) of the Exchange Act, 15 U.S.C. $\$ 78 \mathrm{~m}(\mathrm{~b})(2)(\mathrm{B})$.
}

\footnotetext{
Revista Ballot - Rio de Janeiro, V. 1 N. 2, Setembro/Dezembro 2015, pp. 22-36

ballot http://www.e-publicacoes.uerj.br/index.php/ballot
} 
First, it is highly important that companies subject to both the FCPA and the Brazilian Anticorruption Act adopt very clear and straightforward internal rules in their compliance programs. Once the company determines which law is the strictest in relation to a given matter, this should be the standard to be followed and the guidance to internal personnel should be clear and involve everyone within the company, from the CEO to the low level employee.

Second, as the Brazilian Anticorruption Act still lacks some guidance regarding some key aspects, it is highly important that companies follow a good faith and transparent behavior in relation to their compliance with the law and relation with the authorities. If a given issues falls within a gray area of the law, it is always advisable that the company considers the Brazilian practice and history, the international best practice (including the FCPA guidance) and tries to interpret the law in with as much good faith as possible. This approach will certainly help the companies in the interaction with the local authorities if they are required by them to given explanations regarding a given practice. 
Recebido em: 05/12/2015

Aceito em: 15/12/2015

\section{Como citar}

MONTEIRO, Alberto. Anticorruption in Brazil: How Brazilian companies should deal with requirements of the FCPA and of the Brazilian Anticorruption Act. Ballot. Rio de Janeiro: UERJ. Volume 1 Número 2 Setembro/Dezembro 2015. pp. 22-36. Disponível em: [http:// www.e-publicacoes.uerj.br/index.php/ballot]

\section{(C) $(\Theta \odot$}

A Revista Ballot está licenciada sob uma licença Creative Commons Atribuição - Não Comercial - Compartilha Igual 3.0 Não Adaptada. 